\title{
SISTEM INFORMASI PENJUALAN BERBASIS WEB PADA GENOM BAG PURWOKERTO
}

\author{
1) Tasiati, 2) Corie Mei Hellyana \\ 1) Manajemen Informatika, AMIK BSI Purwokerto \\ tasiati0705@bsi.ac.id \\ 2) Manajemen Informatika, AMIK BSI Tegal \\ corie.cma@bsi.ac.id
}

\begin{abstract}
In this globalization era of computer technology is very influential in terms of business. With the presence of internet technology, everyone or company can do business more easily. However utilizationtechnologynot yet used effectively on Genom Bag. Marketing of Genom Bag limited in Purwokerto area so Genom Bag need existence information system sales bag web based as promotion media to reach extensive people and abridging of consumers to do purchase transaction. That is why the writer tries to make Final Assignment concerning information system sales bag web based in Genom Bag Purwokerto. The making of this website was developed using SDLC (System Development Life Cycle) with waterfall model. Waterfall model start from Analysis of software requirements, design, creation program code, testing, and maintenance. Implementation of This Final Assignment is information system sales bag web based in Genom Bag Purwokerto that intent on expand marketing area, abridging of people to access information of shopping, and abridging of consumers to purchasing product and increase products sales so the making of this website expected can increase revenue of Genom Bag.
\end{abstract}

\section{Keywords: Information System, Website, Sales Bag.}

Abstrak - Pada era globalisasi sekarang ini teknologi komputer sangat berpengaruh dalam hal bisnis. Dengah hadirnya teknologi internet, setiap orang atau perusahaan dapat melakukan bisnis lebih mudah. Namun pemanfaatan teknologi belum dimanfaatkan secara efektif pada Genom Bag. Pemasaran Genom Bag masih terbatas di daerah Purwokerto, sehingga Genom Bag membutuhkan adanya suatu sistem informasi penjualan tas berbasis web sebagai media promosi untuk menjangkau masyarakat luas serta untuk memudahkan konsumen untuk melakukan transaksi pembelian. Untuk itulah penulis membuat sistem informasi penjualan tas berbasis web pada Genom Bag Purwokerto. Pembuatan websiteini dikembangkan menggunakan SDLC (System Development Life Cycle) dengan model air terjun (waterfall). Model waterfall dimulai dari analisis kebutuhan perangkat lunak, desain, pembuatan kode program, pengujian dan pendukung atau pemeliharaan. Implementasi dari penelitian adalah sebuah Sistem Informasi Penjualan Tas Berbasis Web Pada Genom Bag Purwokerto,yang bertujuan untuk memperluas area pemasaran, memudahkan masyarakat untuk mengakses informasi perbelanjaan, memudahkan konsumen dalam membeli produk, dan meningkatkan penjualan produk sehingga pembuatan website ini diharapkan dapat meningkatkan pendapatan Genom Bag.

\section{Kata Kunci: Sistem Informasi, Website, Penjualan Tas.}

\section{A. PENDAHULUAN}

Pada era globalisasi sekarang ini, manusia mengenal teknologi yang semakin maju untuk mempermudah melakukan berbagai kegiatan dalam kehidupan. Teknologi komputer memegang peranan penting dalam menunjang kelancaran aktivitas pekerjaan.Saat ini dunia telah mengenal suatu teknologi yang disebut dengan internet. Dengan komputer yang telah terkoneksi dengan internet, setiap orang dapat memperoleh dan menyampaikan berbagai informasi secara cepat tanpa batasan ruang dan waktu. Kini dengan hadirnya internet, manusia dapat melakukan bisnis lebih mudah.
Teknologi internet berdampak cukup besar pada dunia bisnis (e-commerce) dengan dibukanya jalur perdagangan online sangat memudahkan bagi calon konsumen untuk melihat informasi produk, memesan, ataupun melakukan pembayaran. Itu berarti transaksi penjualan secara online mempunyai calon konsumen yang potensial dari seluruh dunia. Kemajuan teknologi ini menuntut seseorang untuk selalu berinovasi dalam menghadapi era persaingan yang semakin ketat.

Namun pemanfaatan teknologi informasi belum dimanfaatkan secara efektif pada Genom Bag. Genom Bag merupakan suatu usahayang bergerak di bidang penjualan tas yaitu tas ransel dan tas alat musik. Genom 
Bag beralamat di Jalan Sunan Bonang, Dukuhwaluh RT 01 RW 05, Purwokerto. Pemasaran Genom Bag masih terbatas di daerah Purwokerto, sehingga Genom Bag membutuhkan adanya suatu sistem informasi penjualan tas berbasis web sebagai media promosi untuk menjangkau masyarakat luas serta untuk memudahkan konsumen untuk melakukan transaksi pembelian dalam waktu kapanpun.

Dengan adanya pemanfaatan teknologi informasi terutama dengan website, diharapkan Genom Bag dapat meningkatkan pendapatan serta dapat mengefisiensikan waktu dalam proses pelayanan teradap konsumen.

\section{B. TINJAUAN PUSTAKA}

\section{Sistem Informasi}

Menurut Sutabri (2012:10) "Suatu sistem dapat diartikan sebagai suatu kumpulan atau himpunan dari unsur, komponen, atau variabel yang terorganisir, saling berinteraksi, saling tergantung satu sama lain, dan terpadu". Menurut Darmawan dan Fauzi (2013:2) "Informasi merupakan hasil dari pengolahan data, akan tetapi tidak semua hasil dari pengolahan tersebut bisamenjadi informasi, hasil pengolahan data yang tidak memberikan makna atau arti serta tidak bermanfaat bagi seseorang bukanlah merupakan informasi bagi orang tersebut". Menurut Darmawan dan Fauzi (2013:13) "Sistem informasi merupakan kumpulan dari sub-subsistem yang saling berhubungan satu sama lain, dan bekerja sama secara harmonis untuk mencapai satu tujuan, yaitu mengolah data menjadi informasi yang berguna". Sub-subsistem tersebut merupakan pengelompokan dari beberapa komponen yang lebih kecil, bagaimana mereka berkelompok bergantung pada interpretasi mereka.

\section{Internet}

Menurut Winarno dkk (2015:1) "Internet sebetulnya singkatan dari kata Interconnected Networking. Networking artinya jaringan, sedang Interconnected berarti saling berkaitan/terkoneksi. Sehingga internet adalah jaringan komputer yang saling terkoneksi".

\section{Website}

Menurut Madcoms (2011:1) "Website adalah sebutan bagi sekelompok halaman web (web page), dan umumnya merupakan bagian dari suatu nama domain (domain name) atau sub domain dalam World Wide Web (WWW) di internet".
4. E-Commerce
Menurut Wahana (2011:32) "E-Commerce atau Electronic Commerce merupakan

distribusi, penjualan, pembelian, pemasaran barang dan jasa melalui sistem elektronik seperti internet". E-Commerce dapat melibatkan transfer dana elektronik, pertukaran data elektronik, sistem manajemen inventori otomatis, maupun sistem pengumpulan data otomatis.

\section{PHP (PHP Hypertext Preprocessor)}

Menurut Wahana (2011:14) "PHP merupakan bahasa pemrograman yang digunakan untuk membuat program website dimana kode program yang telah dibuat dikompilasi dan dijalankan pada sisi server untuk menghasilkan halaman website yang dinamis".

Menurut Madcoms (2011:11) "PHP (PHP Hypertext Preprocessor) adalah bahasa pemrograman yang berjalan dalam sebuah web server dan berfungsi sebagai pengolah data pada sebuah server". Suatu script akan dikenali sebagai script PHP bila diapit oleh tanda berikut ini:

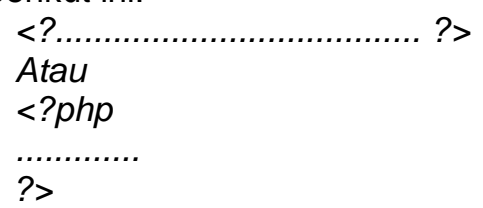

\section{HTML(Hypertext Markup Language)}

Menurut Masrur (2016:23) "HTML (Hyper Text Markup Language) adalah format standar yang digunakan untuk membuat halaman web". Berikut adalah pola dasar HTML:

$<h t m l>$

$<$ heads

$<$ title>Judul Halaman </title>

$</$ head $>$

$<$ body $>$

$$
</ \text { body }>
$$$$
</ \text { html> }
$$

\section{CSS}

Menurut Rozi dan SmitDev (2016:69) "CSSadalah singkatan dari Cascading Style Sheets. CSS adalah bahasa pengkodean yang digunakan untuk menata gaya tampilan halaman web agar lebih cantik dan indah saat ditampilkan di web browser".

\section{JavaScript}

Menurut Winarno dkk (2015:61) "Javascript merupakan bahasa scripting yang lazim ada di dunia web". Javascript sangat berguna karena digunakan untuk banyak teknologi seperti AJAX, PhoneGap, Jquery, Jquery Mobile dan lain sebagainya.

\section{JQuery}

Menurut Wahana (2012:2) "JQuery merupakan pustaka JavaScript yang dibangun untuk mempercepat dan memperingkas serta 
menyederhanakan manipulasi dokumen HTML, penanganan event, animasi dan interaksi Ajax untuk mempercepat pengembangan web".

\section{Basis Data}

Menurut Rosa dan Shalahuddin (2013:43) "Sistem basis data adalah sistem terkomputerisasi yang tujuan utamanya adalah memelihara data yang sudah diolah atau informasi dan membuat informasi tersedia saat dibutuhkan". Pada intinya basis data adalah media untuk menyimpan data agar dapat diakses dengan mudah dan cepat.

11. MySQL

Menurut

Wahana

(2011:15)

"MySQLmerupakan salah satu perangkat lunak untuk sistem manajemen database SQL". Menurut Madcoms (2011:140) "MySQL adalah salah satu program yang dapat digunakan sebagai database, dan merupakan salah satu software untuk databaseserver yang banyak digunakan".

\section{PhpMyAdmin}

Menurut Abdulloh (2015:4) "phpMyAdmin merupakan aplikasi berbasis web yang digunakan untuk membuat database MySQL sebagai tempat untuk menyimpan data-data website".

\section{XAMPP}

Menurut Abdulloh (2015:5) "XAMPP adalah salah satu paket installer yang berisi apache yang merupakan web server tempat menyimpan file-file yang diperlukan website, dan phpmyadmin sebagai aplikasi yang digunakan untuk perancangan database MySQL".

\section{Adobe Dreamweaver CS5}

\section{Menurut Madcoms}

(2011:13)

"Dreamweaver adalah sebuah HTML editor profesional untuk mendesain web secara visual dan mengelola situs atau halaman web". Dreamweaver merupakan software utama yang digunakan oleh Web Designer maupun Web Programmer dalam mengembangkan suatu situs web, karena dreamweaver mempunyai ruang kerja, fasilitas dan kemampuan yang mampu meningkatkan produktifitas dan efektivitas dalam desain maupun membangun suatu situs web.

\section{Photoshop CS6}

Menurut Wahana (2011:18) "Photoshop merupakan perangkat lunak editor citra buatan Adobe System yang digunakan untuk mengolah gambar". Photoshop memiliki banyak fitur yang dapat membantu pengolahan grafis seperti History Bursh Tool, Eraser Tool, Path Selection Tool, Pen Tool, Brush Tool, dan lain-lain.

\section{Model Pengembangan Perangkat Lunak}

SDLC atau Software Development Life Cycle atau sering disebut juga System Development Life Cycle adalah proses mengembangkan atau mengubah suatu sistem perangkat lunak dengan menggunakan modelmodel dan metodologi yang digunakan orang untuk mengembangkan sistem-sistem perangkat lunak sebelumnya.

Menurut Rosa dan Shalahuddin (2013:28) Model SDLC air terjun (waterfall) sering disebut model sekuensial linier (sequential linear) atau alur hidup klasik (classic Life cycle). Model air terjun menyediakan pendekatan alur hidup perangkat lunak secara sekuensial atau terurut dimulai dari analisis, desain, pengodean, pengujian dan tahap pendukung (support).

\section{Entity Relationship Diagram(ERD)}

Menurut Rosa dan Shalahuddin (2013:50) pemodelan awal basis data yang paling banyak digunakan adalah menggunakan Entity Relationship Diagram(ERD). ERDdikembangkan berdasarkan teori himpunan dalam bidang matematika. ERD digunakan untuk pemodelan basis data relasional.

\section{Logical Record Structure(LRS)}

Menurut Hasugian dan Shidiq (2012:608) mengemukakan bahwa: Logical Record Structure (LRS) merupakan sebuah model sistem yang digambarkan dengan sebuah diagram-ER akan mengikuti pola/aturan pemodelan tertentu dalam kaitannya dengan konversi ke LRS, maka perubahan yang terjadi adalah mengikuti aturan-aturan sebagai berikut: setiap entitas akan diubah kebentuk kotak, sebuah atribut relasi disatukan dalam sebuah kotak bersama entitas jika hubungan yang terjadi pada diagram-ER 1:M (relasi bersatu dengan cardinality $M$ ) atau tingkat hubungan 1:1 (relasi bersatu dengan cardinality yang paling membutuhkan referensi), sebuah relasi dipisah dalam sebuah kotak tersendiri (menjadi entitas baru) jika tingkat hubungannya M:M (many to many) dan memiliki foreign key sebagai primary key yang diambil dari kedua entitas yang sebelumnya saling berhubungan.

\section{METODE PENELITIAN}

1. Metode Pengembangan Perangkat Lunak

Metode yang digunakan pada pengembangan perangkat lunak ini menggunakan model water fall (Rosa dan Shalahuddin, 2013:29) yang terbagi menjadi lima tahapan, yaitu: 
a) Analisis Kebutuhan Perangkat Lunak Proses pengumpulan kebutuhan dilakukan secara intensif untuk menspesifikasikan kebutuhan perangkat lunak agar dapat dipahami perangkat lunak seperti apa yang dibutuhkan oleh user.

b) Desain

Desain perangkat lunak adalah proses multi langkah yang fokus pada desain pembuatan program perangkat lunak termasuk struktur data, arsitektur perangkat lunak, representasi antar muka dan prosedur pengodean.

c) Pembuatan Kode Program

Pada tahap ini, perancangan perangkat lunak direalisasikan sebagai serangkaian program atau unit program. Pengodeannya menggunakan bahasa pemrograman PHP Hypertext Preprocessor (PHP), Hyper Text Markup Language (HTML), JavaScript, Cascading Style Sheet (CSS), dan Database MySQL.

d) Pengujian

Pengujian fokus pada perangkat lunak dari segi lojik dan fungsional serta memastikan bahwa semua bagian sudah diuji sehingga keluaran yang dihasilkan sesuai dengan yang diinginkan. Pengujian web menggunakan blackbox testing.

e) Pendukung atau Pemeliharaan

Tidak menutup kemungkinan sebuah perangkat lunak mengalami perubahan ketika sudah dikirimkan ke user, perubahan bisa terjadi karena adanya kesalahan yang muncul dan tidak terdeteksi saat pengujian atau perangkat lunak harus beradaptasi dengan lingkungan baru. Tahap pendukung atau pemeliharaan dapat mengulangi proses pengembangan mulai dari analisis spesifikasi untuk perubahan perangkat lunak yang sudah ada. Untuk mendukung dan memelihara dengan melakukan pembaruan konten website dan membackup data secara berkala.

\section{Metode pengumpulan Data}

Metode pengumpulan data yang digunakan oleh dalam melakukan penelitian ini adalah:

a) Observasi

Metode untuk memperoleh data-data dengan mengamati langsung pada Genom Bag dan mencatat hal-hal yang berhubungan dengan permasalahan secara lengkap dan sistematis sehingga hasil dari pengamatan tersebut dapat digunakan sebagai bahan penulisan laporan.

b) Wawancara

Metode pengumpulan data dengan cara bertanya jawab secara langsung kepada pemilik Genom Bag tentang sistem penjualan yang digunakan dan permasalahan yang di hadapi Genom Bag.

c) Studi Pustaka

Metode pengumpulan data dengan cara mencari bahan referensi dan mempelajari buku-buku yang berkaitan.

\section{HASIL DAN PEMBAHASAN}

\section{Analisis Kebutuhan}

Analisis kebutuhan merupakan langkah awal untuk menentukan perangkat lunak yang dihasilkan. Perangkat lunak yang sesuai dengan kebutuhan pengguna sangat tergantung pada keberhasilan dalam melakukan analisa kebutuhan.

\section{Analisa Kebutuhan Pengguna}

Dalam menganalisis kebutuhan pengguna pada website Genom Bag, penulis membagi kedalam tiga kebutuhan pengguna yaitu kebutuhan pengujung, kebutuhan member, dan kebutuhan administrator.

a) Pengunjung

1) Pengunjung membutuhkan informasi tentang produk, harga produk, cara pemesanan, tentang perusahaan, syarat dan ketentuan belanja dan pencarian produk.

2) Pengunjung membutuhkan layanan pendaftaran member untuk dapat menjadi member sehingga dapat melakukan transaksi pemesanan.

b) Member

1) Member membutuhkan informasi tentang produk, harga produk, cara pemesanan, keranjang belanja, tentang perusahaan, syarat dan ketentuan belanja, dan pencarian produk.

2) Member membutuhkan layanan login untuk melakukan transaksi pemesanan.

3) Member membutuhkan layanan testimoni untuk dapat memberikan pesan, kritik, atau saran.

c) Administrator

1) Administrator membutuhkan layanan untuk dapat mengelola data-data, diantaranya: data kategori, data produk, data profil, data provinsi, data kota, data kurir, data bank, data cara pemesanan, data syarat dan ketentuan, data 
member, data admin, dan data pemesanan.

2) Administrator membutuhkan layanan untuk memberikan respon pada buku tamu dan layanan sortiruntuk menampilkan/tidak menampilkan buku tamu dan testimoni yang diberikan pengunjung/member.

3) Administrator membutuhkan laporan penjualan dan laporan barang yang terjual.

\section{Analisa Kebutuhan Sistem}

Analisa kebutuhan sistem mencakup hak akses, pengelolaan data, dan keamanan.

a) Hak Akses

1) Pengunjung

(a) Pengunjung dapat melihat informasi beranda, produk, cara pemesanan, buku tamu, testimoni, pencarian produk, syarat dan ketentuan, dan tentang kami.

(b) Pengunjung dapat melakukan pendaftaran member dengan mengisi data diri pengunjung pada form pendaftaran.

(c) Pengunjung dapat melakukan transaksi pemesanan setelah terdaftar sebagai member.

2) Member

(a) Member dapat melihat informasi beranda, produk, cara pemesanan, keranjang belanja, buku tamu, testimoni, tentang kami, syarat dan ketentuan dan pencarian produk.

(b) Member dapat melakukan login untuk melakukan transaksi pemesanan, melihat/mengubah data member, melihat histori pesanan, melakukan konfirmasi pembayaran dan mengubah password member.

(c) Member dapat menuliskan pesan, kritik, atau saran pada menu testimoni.

3) Administrator

(a) Administrator dapat melakukan login ke halaman administrator dengan menginputkan nama dan password.

(b) Administrator dapat mengelola data kategori, data provinsi, data kota, data kurir, data bank, data profil, data produk, data tentang kami, data cara pemesanan, data syarat dan ketentuan, data pemesanan, data member, dan data administrator. (c) Administrator dapat mengganti status pesanan member.

(d) Administrator dapat memberikan respon pada buku tamu yang masuk, dan dapat menampilkan/tidak menampilkan buku tamu dan testimoni.

(e) Administrator dapat melihat laporan penjualan dan laporan barang yang terjual dengan menginputkan tanggal awal dan tanggal akhir.

b) Pengelolaan Data

Data-data yang dibutuhkan dalam pembuatan website Genom Bag antara lain:

1) Data profil berupa deskripsi usaha, alamat usaha, nomor telepon, email, dan akun media sosial.

2) Data produk berupa nama produk, deskripsi produk, gambar produk dan harga produk.

3) Data bank berupa nama bank dan nomor rekening pemilik untuk proses pembayaran dari member.

4) Data provinsi yang berisi nama provinsi untuk pemrosesan pengiriman barang.

5) Data kota yang berisi nama kota dari setiap provinsi.

6) Data kurir yang berisi nama agen jasa pengiriman barang.

7) Data ongkir yang berisi biaya untuk pengiriman barang dari setiap kurir.

c) Keamanan

Dalam pembuatan website Genom Bag membutuhkan pengamanan. Kebutuhan sistem mengenai keamanan website ini adalah:

1) Membutuhkan username, password, dan kode verifikasi yang benar pada setiap member yang akan melakukan login.

2) Membutuhkan nama dan password yang benar pada setiap administrator yang akan melakukan login.

3) Membutuhkan layanan perubahan password dari setiap member dan administrator.

4) Menggunakan validasi pada setiap form.

\section{Perancangan Perangkat Lunak}

Rancangan tampilan pada website ini dibuat sesuai dengan kebutuhan Genom Bag dalam hal memberikan informasi kepada para pengguna internet. Tampilan pada website ini 
dibuat cukup sederhana. Hal ini bertujuan agar mempermudah pengunjung/member untuk mengakses informasi yang ada. Dalam perancangan perangkat lunak ini terdapat rancangan antar muka, rancangan basis data, dan rancangan struktur navigasi.

a) Rancangan Antar Muka

1) Rancangan Antar Muka Beranda Halaman beranda merupakan halaman utama website.

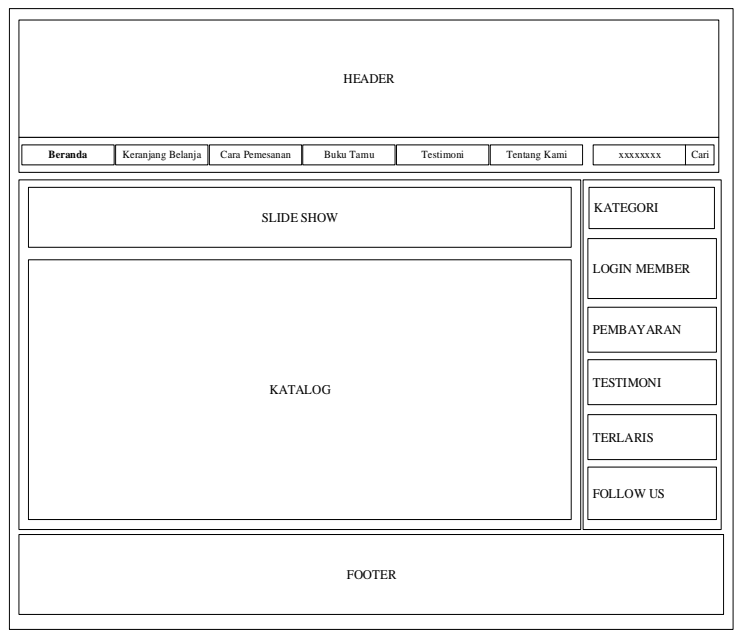

Gambar 1. Rancangan Antar Muka Beranda

2) Rancangan Antar Muka Katalog Produk

Halaman ini menampikan produkproduk yang tersedia.

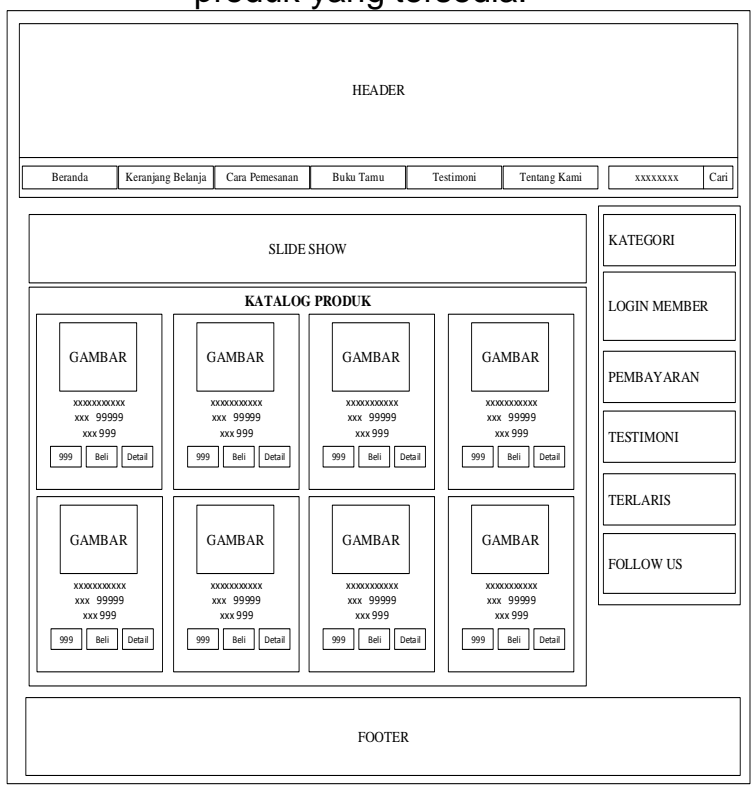

Gambar 2. Rancangan Antar Muka Katalog Produk

3) Rancangan Antar Muka Keranjang Belanja

Halaman ini menampilkan keranjang belanja atau rincian produk dan total harga dari produk yang dipesan.
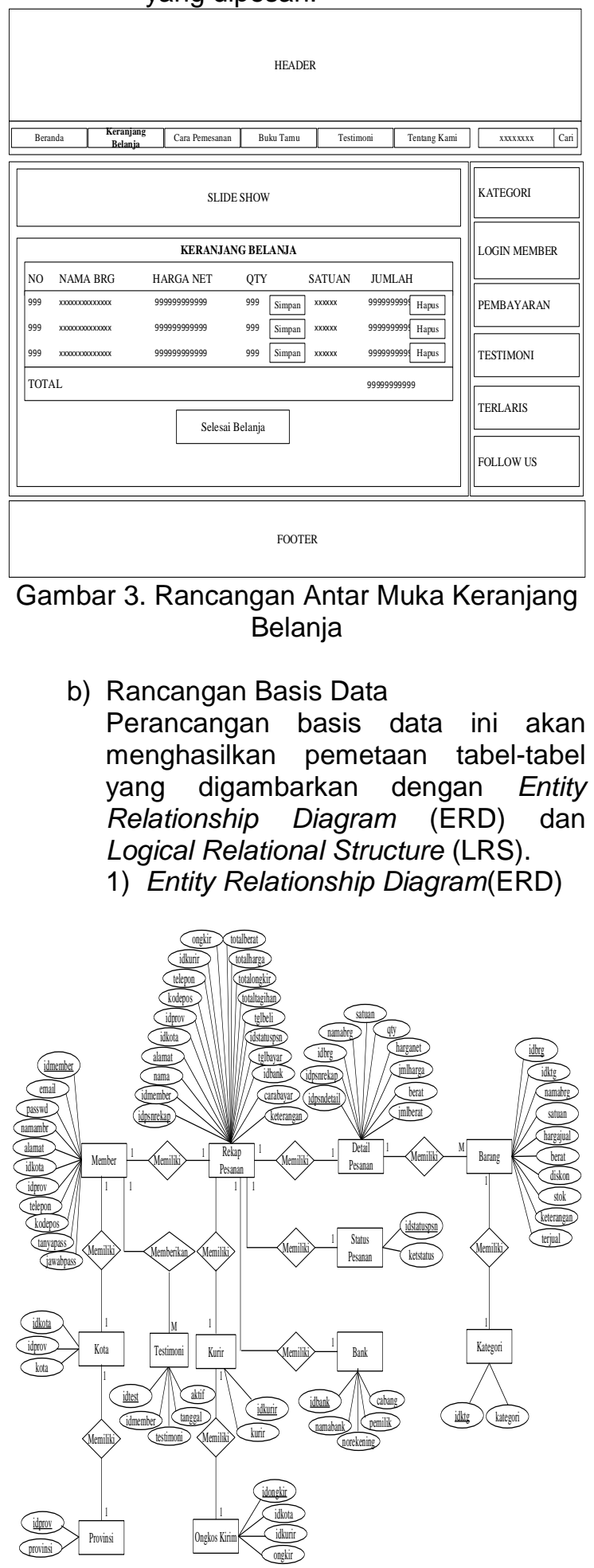

Gambar 4. Entity Relationship Diagram

(ERD) 


\section{2) Logical Relational Structure(LRS)}

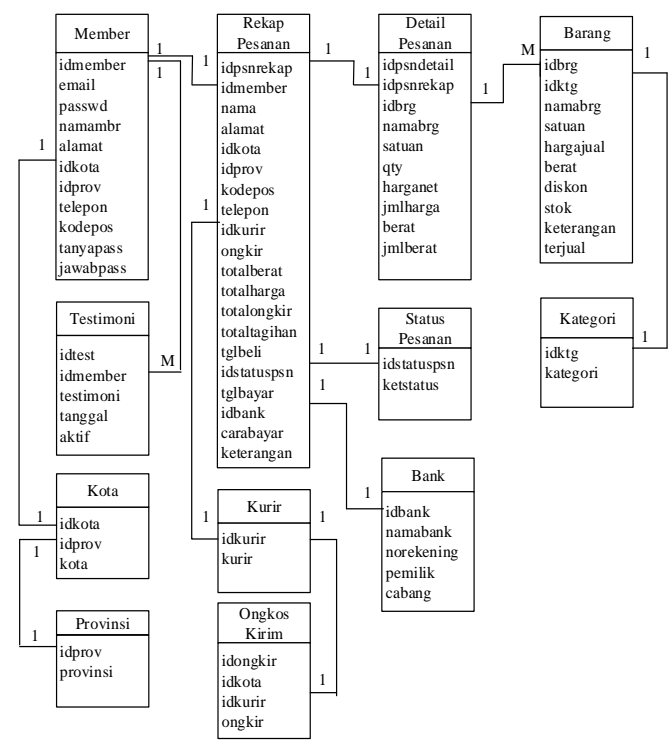

Gambar 5. Logical Relational Structure (LRS)

\section{Implementasi}

Implementasi rancangan antar muka pada website e-commerce berdasarkan hasil rancangan antar muka sebagai berikut:

a) Halaman Beranda

Halaman beranda tampil saat pertama website Genom bag di akses. Halaman beranda menampilkan katalog produk untuk kategori semua produk.

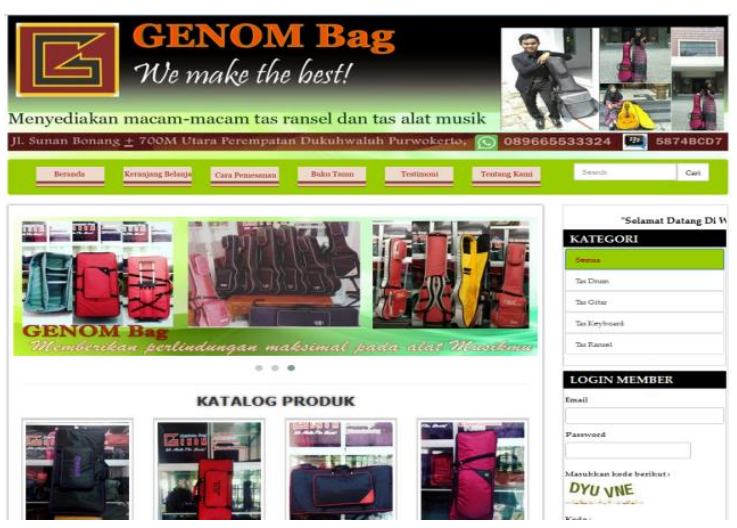

Gambar 9. Halaman Beranda

b) Halaman Beranda Administrator

Halaman ini merupakan halaman utama aplikasi administrator yang tampil setelah administrator berhasil melakukan login. Halaman beranda berisi pesanan yang belum diproses dan buku tamu yang belum di respon.

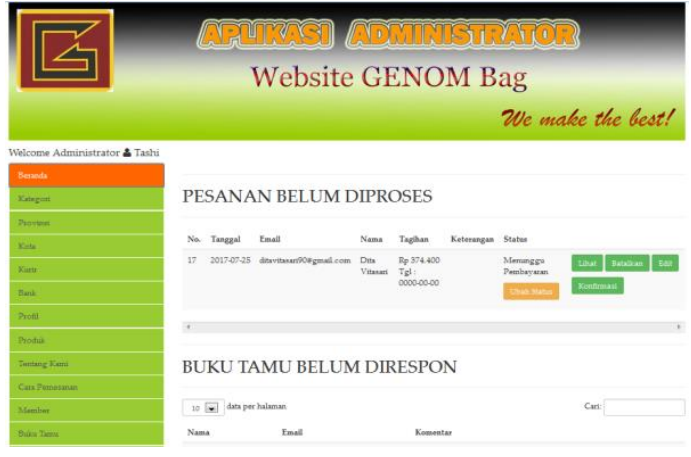

Gambar 10. Halaman Beranda Administrator

\section{E. KESIMPULAN DAN SARAN}

\section{Kesimpulan}

Berdasarkan uraian-uraian yang telah penulis paparkan pada bab-bab sebelumnya, maka penulis dapat menarik beberapa kesimpulan sebagai berikut:

a) Sistem informasi penjualan tas berbasis web ini diimplementasikan untuk memudahkan penjualan Genom Bag agar lebih efektif dan efisien, memudahkan konsumen dalam melakukan transaksi pembelian, serta memudahkan dalam penyimpanan dan pengelolaan data penjualan.

b) Dengan menggunakan website ini Genom Bag dapat memperluas jangkauan pemasaran dan meningkatkan daya saing usaha.

c) Sistem informasi penjualan tas berbasis web ini memberikan solusi bagi Genom Bag untuk meningkatkan omzet penjualan.

\section{Saran-Saran}

Berdasarkan kesimpulan diatas, terdapat beberapa saran yang dapat membantu agar website ini dapat bekerja secara optimal. Saran-saran tersebut antara lain:

a) Memberikan pelatihan kepada administrator mengenai penggunaan aplikasi administrator agar website dapat dijalankan dengan baik dan benar.

b) Rutin melakukan update terhadap konten web, menyesuaikan dengan informasi yang berubah atau bertambah.

c) Perlunya penggantian password administrator secara berkala untuk meningkatkan keamanan.

d) Rutin Melakukan back updatabase untuk mengantisipasi kemungkinan terjadinya hal-hal yang tidak diinginkan seperti hilangnya data karena virus ataupun lainnya.

e) Melakukan evaluasi terhadap kritik dan saran dari pengunjung/member. 


\section{DAFTAR PUSTAKA}

[1] Abdulloh, Rohi. 2015. Web Programming is Easy. Jakarta: PT Elex Media Komputindo.

[2] Andre. 2015. Tutorial Belajar jQuery Part 1: Pengertian jQuery. Diambil dari: www.duniailkom.com/tutorial-belajarjquery-pengertian-jquery/. (08 Mei 2017)

[3] Arief, M. Rudyanto. 2011. Pemrograman Web dinamis Menggunakan PHP \& MySQL. Yogyakarta: C.V Andi Offset.

[4] Darmawan, Deni, dan Kunkun Nur Fauzi. 2013. Sistem Informasi Manajemen. Bandung: PT Remaja Rosdakarya.

[5] EMS, Tim. 2009. Cara Mudah Menjadi Webmaster. Jakarta: PT Elex Media Komputindo.

[6] Hasugian, Humisar, dan Ahmad Nur Shidiq. 2012. Rancang Bangun Sistem Informasi Industri Kreatif Bidang Penyewaan Sarana Olahraga. Semarang: Jurnal Seminar Nasional Teknologi Informasi \& Komunikasi Terapan. (23 Juni 2012)

[7] Hayaty, Mardhiya. 2017. Entity Relationship Diagram. Diambil dari: http://elearning.amikom.ac.id/index.php/d ownload/materi/entity_relationship_diagra m_-_erd.pdf. ( 29 April 2017)

[8] Kadir, Abdul. 2009. Membuat Aplikasi Web dengan PHP dan Database MySQL. Yogyakarta: C.V Andi Offset.

[9] Komputer, Wahana. 2011. Mastering CMS Programming With PHP \& MySQL. Semarang: C.V Andi Offset.

[10] Komputer, Wahana. 2012. Belajar JavaScript Menggunakan JQuery. Yogyakarta: C.V Andi Offset.

[11] Madcoms. 2008. Teknik Mudah Membangun Website dengan HTML, PHP, Dan MySQL. Yogyakarta: C.V Andi Offset.

[12] Madcoms. 2011. Aplikasi Web Database dengan Dreamweaver dan PHP-MySQL. Yogyakarta: CV Andi Offset.

[13] Madcoms. 2012. JavaScript Untuk Membangun Website Profesional. Yogyakarta: CV Andi Offset.

[14] Madcoms. 2015. Mudah Menggunakan. Internet Untuk Pemula. Yogyakarta: CV Andi Offset

[15] Masrur, Mukhamad. 2016. Pemrograman Web Dinamis Menggunakan Java Server Pages dengan Database Relasional MYSQL. Yogyakarta: C.V Andi Offset.

[16] Nugroho, Bunafit. 2008. Latihan Membuat Aplikasi Web PHP dan MySQL dengan Dreamweaver. Yogyakarta: Gava Media.
[17] Rozi, Zaenal A., dan SmitDev Community. 2016. Modern Web Design. Jakarta: PT Elex Media Komputindo.

[18] S., Rosa A., dan M. Shalahuddin. 2013. Rekayasa Perangkat Lunak Terstruktur dan Berorientasi Objek. Bandung: Informatika Bandung.

[19] Sutabri, Tata. 2012. Konsep Sistem Informasi. Yogyakarta: CV Andi Offset.

[20] Sutopo, Ariesto Hadi. 2007. Pemrograman Flash Dengan PHP dan MySQL. Yogyakarta: Graha Ilmu.

[21] Winarno, Edy, Ali Zaki dan SmitDev Community. 2015. Panduan Lengkap Berinternet. Jakarta: PT Elex Media Komputindo. 